J O U R A L O F

French and Francophone Philosophy
REVUE DE L A

philosophie française et de langue française

\title{
On Jewish Being: Notes on Jean Améry
}

Andrew Benjamin

Journal of French and Francophone Philosophy - Revue de la philosophie française et de langue française, Vol XXIV, No 3 (2016) 157-172.

\author{
Vol XXIV, No 3 (2016) \\ ISSN 1936-6280 (print) \\ ISSN 2155-1162 (online) \\ DOI 10.5195/jffp. 2016.793 \\ www.jffp.org
}

\section{(c) EY-NC-No}

This work is licensed under a Creative Commons Attribution-Noncommercial-No Derivative Works 3.0 United States License.

\section{ULIS D-Sunt}

This journal is operated by the University Library System of the University of Pittsburgh as part of its D-Scribe Digital Publishing Program, and is co-sponsored by the University of Pittsburgh Press 


\title{
On Jewish Being
}

Notes on J ean Améry

\author{
Andrew Benjamin \\ Monash University
}

Le juif du Livre n'est pas fidèle, mais l'infidèle, l'insurgé, l'exilé: Celui pour qui le livre est chaque fois autre au risqué de n'etre plus. ${ }^{1}$

- Edmond Jabès

1

That the question of identity takes on a sense of urgency, one with its own possibilities and impossibilities, the moment that identity is bound up with death, is hardy surprising. ${ }^{2}$ What follows are a series of reflections on the question of identity, Jewish identity, raised by Jean Améry's remarkable text On the Necessity and Impossibility of Being a Jew (Über Zwang und Unmöglichkeit, Jude zu sein). ${ }^{3}$ Améry's text was of course published in the wake of his own experiences as an active member of the resistance, as having been imprisoned in Auschwitz and as the victim of torture. Philosophically, rather than biographically, if there were a point of comparison, then it is to Levinas's 1947 text Etre juif. ${ }^{4}$ Both pose the problem of how the question of Jewish identity, Jewish being, is to be understood in the wake of the Shoah. The meaning of the formulations - Jude zu sein, Jude sein, Etre juif, Jewish being - delimits the question to be addressed. ${ }^{5}$ This will be the case even if its point of address, namely what the question stages, is itself far from straightforward. Moreover, while what is demanded within that question is itself philosophically important, it is equally the case that the question of Jewish being is at work within both communities and synagogues across the Jewish world. As a consequence it is as much a philosophical question as it is one that has a structuring effect on how Jewish survival is conceived (and thus equally on what that survival is taken to be). How survival is understood is an issue that continues to exert its force. Who is the subject of survival? What is the subject of survival? Who or what has been subjected to the issue of survival? Survival is both more nuanced and 
complex than the brute fact of an afterlife. Jewish being as a present question - a question of the present - continues therefore. ${ }^{6}$

Nothing can diminish the horrors through which Améry lived. Not only were the marks of humanity taken from those who endured it, language was also debilitated. Worlds were altered. Time itself came to be recast as a result. ${ }^{7}$ The experience of time stripped of the feint of the natural had to reemerge as a site of genuine engagement (though equally of an always possible sustained failure to engage). ${ }^{8}$ Memory as an act, and memorialization as a set of practices which move between the liturgical and the architectural, are sustained as legacies without any one determined form being able to predominate. ${ }^{9}$ As has been suggested what continuity means is a question for which answers that summarize and complete are no longer at hand. To compare genocides is to trivialize them. Each one is beyond comparison precisely because each has a singularity that has to be maintained. Questions of guilt, victimhood and forgiveness differ. ${ }^{10}$ That with which differing forms of reconciliation takes place become banal once they are generalized.

The Nazis had a number of victims. Overwhelmingly, however, they were Jews. Of concern here, in this encounter with Améry, is the assault that took place on the Jews. Who were these Jews? The Nazi's Jews were assaulted, though they were assaulted after having been constructed to be assaulted. The act of construction allows for the moment of individualization, that is, identifying the Jews as no longer part of the common. Thus they no longer occupy a place within the world, hence the world is recreated in order to be Judenfrei. Once recreated it then becomes the place occasioning literal violence. ${ }^{11}$ Individuation, within this set up, a process which can equally be understood as a form of violence, occurs in order that those individuated can then become the be subjected to what would now be sanctioned literal violence. The contention here therefore is that this construction has a twofold effect. In the first instance it created Jews from within a setting that gave rise as much to forms of non-identification, as it did to forms of identification. And in the second, it created Jews in a way that undid dignity. At work were processes leading to the creation of a way of being that can be reformulated as being-without-dignity. A position that was produced and which would have marked in advance those that had been so produced. The question of Jewish being was resolved in one direction by National Socialism. It took place as a result of the laws enacted in its name, the imprisoning, torture and death that then ensued, sustained throughout by the creation and recreation of those defined as being-withoutdignity. An important qualification needs to be introduced here. This creation is the reduction of those individuated to what Walter Benjamin would have identified as "mere life." 12 It is a process. Hence, pace Agamben, neither being nor life could have been "bare" for the exact reason that existence would always have borne the mark of this form of production. ${ }^{13}$ 
The tattoo is the refusal of bareness. Partly as a result of processes of subject creation, individuation, within this setting definition and self-definition did not always coincide. This is the predicament. Note the way Améry begins his account:

If today discomfort arises in me when a Jew takes it for granted, legitimately, that I am part of his community, then it is not because I don't want to be a Jew, but only because I cannot be one. And yet must be one. (nur weil ich es nicht sein kann. Und es doch sein muß.) ${ }^{14}$

The müssen (the "must") in the und es doch sein muß has a twofold effect. It brings into play both a duty and an obligation. The sense of obligation is complex. It allows for set up in which the subject in question is positioned as having been obligated by a form of externality; thus the subject is obligated from the outside.

At the outset what is at work within this formulation is a specific address to the question of Jewish being. Specificity occurs in the precise sense that it is posed in terms of being (sein) and not being (nicht sein). Enacted here therefore is a complex set of connections between self-identification and having been identified. ${ }^{15}$ As result, reference is already made to the Jews' own relation to community and thus to the place of that community, as well as any wider sense of the common that may prevail. (And thus the place of the apparently singular within the created common.) The latter, the singular's relation to the common, can be understood as a version of the "Jewish question." 16 Though what is also clear is the way that this complex structure of identity is set in place has to have had a determining effect on the way this "question" is posed. Within the structure created by this "question" one domain is of necessity refracted through the other. There can be no simple separation. And this is the case even if such a separation were thought to be possible. The "Jewish question" will always have been informed by differing ways in which the constitution of identity occurs. ${ }^{17}$ Here that constitution can be thought, following the direction of Améry's own argumentation, in terms of the continual creation of a being-withoutdignity.

If there is a difficulty with Améry's work, then it is not with either the strength or perceived weakness in any of his modes or forms of argumentation. The difficulty inheres in the demands made by his writings. These writings are at once reflective and autobiographical, at once descriptive and confessional. Within them there is a stark openness. To read them is to have to read without their hold having been loosened; flinching without flinching. There is no way out. And yet, responding to his work cannot adopt the same tone. There would be a form of injustice within such an act. Améry is acutely aware of the singularity of his own experience. The truth that results from that singularity is clear; namely, that one set of experiences cannot be countered by another. To respond to the evocation of 
the body with another such evocation is to have missed what is at stake. Améry writes "I." He writes the history of an "I," that to which that "I" was subject and thus, more emphatically, of the constitution of that " $\mathrm{I}$ " as a beingwithout-dignity. To reiterate the point that has already been suggested, this act of constitution, precisely because what it constitutes is a being-withoutdignity, and thus in Améry's terms as "someone to be murdered" (ein zu Ermordender), is an act of violence; an act of violence enjoining violence. ${ }^{18}$ (It will be essential to return to this point.) The singularity of his predicament, the predicament of his body, gives rise to the question: By what right could "I" - an "I" and thus another "I"- be written in response? If it were more than the countering of one experience with another, then this " $\mathrm{I}$ " would be a naturalization of the " $\mathrm{I}$ " thereby giving rise to a merely putative universality. As a result Améry's entire project would then have been betrayed. Naturalism would become a form of philosophical failure. Performed failure. A failure to have understood that what Améry writes is located within a setting of contested affirmation. Rebellion is already the undoing of an enforced nature though not in the name of a prior nature (which would be no more than a merely suggested and therefore ultimately illusory "real" nature).

\section{2}

Améry recounts an experience. He cannot respond, as does a fellow concertgoer, another Jew, to the singing of the words Sch'ma Israel in a performance of Arnold Schonberg's A Survivor From Warsaw. Hearing, but not having been touched, touched in the sense of having been able to respond emotionally, occurs within a setting that is marked by both a distancing and more significantly by a sense of identity that links a feeling of belonging to a prevailing "catastrophe." Améry writes:

To be a Jew (Jude sein), I cannot do it emotionally, (ich kann es nicht in Ergriffenheit) I thought to myself afterwards, is not possible for me, I can be a Jew only in fear and anger, when in order to attain dignity, fear transforms itself into anger. "Hear, oh Israel" is not my concern (geht mich nichts an). Only a "hear, oh world" (Höre Welt) wants angrily to break out from within me. The six-digit number on my forearm demands it. That is what the awareness of catastrophe, the dominant force of my existence (meiner Existenz), requires. ${ }^{19}$

There is a divide, a breach. Hear, oh Israel are words that do not touch. He remains unmoved. He could not have been clearer. What they evoke, he writes, "is not my concern" (geht mich nichts an). (This is the "impossibility" of being a Jew that is announced in the text's title.) There is another set of words, a different formulation that he would seek to deploy. They are words that announce a type of a move. A move that both reinforces the injustice of 
any response that begins " $\mathrm{I}$ " and, at the same time, names that which endures as essential if the predicament presented by Améry is to become a genuine site of engagement. The other demand, one that arises, is to voice that which is unvoiced namely, to reiterate his formulation, "hear, oh world" (Höre Welt). (This is the "impossibility" of not being a Jew that the title also announces.)

The world is there. Nonetheless questions abound. How is this evocation of the "world" to be understood? What is there in this voicing to the world that would also be a voicing of the world? What would it mean to speak to the world, while also speaking of the world? Again a doubling insists. While this passage cited above needs to be incorporated into the text as a whole, what has to be retained is the centrality of what is named here as the "world." There are two elements that are important. In the first instance there is the introduction of the "world" and thus what can be thought as the complex problem of the relation between an enforced particularism, this is the particularism that seeks the world as the result of an insistent nonidentification with the Shema, and the world as that which stands opposed to this particularism (and its being this particularism, the particularity of Jewish being, is an essential component of what is at stake here). In the second there is the more general question of place. What is evoked, what is called into consideration within the formulation, "hear oh world," is the world as place and the place of the Jews within it, though equally a place within that world for the Jews. And while what continues is the problem of how the identity staged by Jewish being is to be understood, what the formulation "hear, oh world" (Höre Welt) brings to the fore is the recognition that being is worldly, and thus it is always placed. The place of the world must be central. A return will need to be made to the "world" since it will be in terms of the world that the interplay between violence and identity is best approached. As will be noted violence, when understood as a philosophical term, is integral to any account of the creation of identities such a being-withoutdignity and thus their worlds. Violence is not just an individual act. It is worldly in part because while sanctioned by the world that world is configured to deny its victim a place within it. Taken together this is the event of violence.

\section{3}

As has already been intimated, one of the key terms at work in "On the Necessity and Impossibility of Being a Jew" is "dignity" (Würde). The term is central to the development of the philosophical after the Shoah and indeed to deploy Arendt's terminology after the "totalitarian." Her general claim that in the wake of the totalitarian dignity needs a "new guarantee" remains a powerful argument. ${ }^{20}$ Indeed, these reflections on Améry can be situated within that wider project. The term "dignity" continues to appear in this 
particular text. It appears, moreover, within Améry's larger set of writings. Dignity returns. He asks the question: “What is dignity?" The question endures. At times answers are suggested. They are linked to the erotic, to free speech, to a sense of "physical convenience." 21 While there are allusions within these tentative identifications, dignity fails to be captured by these possibilities. They allude to it but do not address it directly. What then would be the address of dignity? To take another stand, another way through, and thus to engage the question differently would be to argue that dignity is linked to a type of freedom and therefore it amounted to the ability to choose within a situation. Dignity would then be bound to the freedom to act. However, this is a sense of freedom that alludes to what might be called empty intrinsic qualities. While Améry may resist such a formulation it is already there in his attempt to counter the negative with the positive. He writes:

If I were correct that the deprivation of dignity (der Würdeentzug) were nothing other than the potential deprivation of life (Lebensentzug), then dignity would have to be the right to live. ${ }^{22}$

What is problematic, for Améry, within this formulation is the sense of abstraction. The position is inadequate. The inadequacy for Améry is clear. A recourse to abstraction is not the counter to dignity's deprivation. What stands opposed to abstract right, namely the threat of death, would render that right inoperable and hence claims to dignity, equally claims to regain lost dignity, based merely on such a right would have been of no value. Abstraction endures therefore as problem. Hence the force of Arendt's claim that "the world found nothing sacred in the abstract nakedness of being human." 23 The limit of this particular construal of abstraction demands another way through. However, if there were another way of working through this predicament, and here what matters is Améry's own position, then it hinges on how the interplay of the operable and the inoperable is to be understood:

It is certainly true that dignity can be bestowed only by society, whether it be the dignity of some office, a professional or, very generally speaking, civil dignity, and the merely individual, subjective claim ("I am a human being and as such I have my dignity, no matter what you may do or say!") is an empty academic game, or madness. Still, the degraded person (der entwürdigte), threatened with death, is able - and here we break through the logic of the final sentencing - to convince society of his dignity (seine Würde) by taking his fate (sein Schicksal) upon himself and at the same time (zugleich) rising in revolt against it. ${ }^{24}$

Note the double move that occurs at the end of this formulation. Améry is quick to recognize that there is a version of dignity that depends upon its being conferred. And yet, the mere self-assertion of dignity is empty. The 
fundamental point in the way the position is constructed involves the threat of death, and thus the threat of non-being, as the point of departure. And there is, of course, a real correlation between the act of constitution in which being-without-dignity is created and a subsequent death. Being-without-dignity leads to death as the resultant non-being. One allows and thus occasions the other. One is marked and re-marked by the other.) Given that insistent possibility, i.e. the move from being-without identity to non-being - the latter is the realization of the threat that the former brings with it - what then obtains is the need for that affirmation of a form of existence that circumvents this setting and the movement within it. This would be the setting in which life would counter death in the precise sense that the link between being-without identity to non-being would be broken because the possibility of dignity would have been retrieved. As such, in the place of abstraction, it would be life that counters death.

For Améry this becomes the affirmation of identity through an act of revolt. His formulation is precise. Dignity emerges in taking over the question of "fate" (Schicksal) as one's own and thus to resist the enforcing of fate, the state of having been fated. However this is not a single act with a single object. Its formulation involves a doubled presence. There is an insistent zugleich - "at the same time" - that determines this doubling. The taking over of fate and the "rising in revolt" while separate occur together. There is therefore what might be described as an anoriginal at-the-sametimeness; i.e. an-original doubling at the origin. Dignity cannot be thought as a mere intrinsic quality. On the contrary, while intrinsic it has to be acted out. An insistence on the actative obviates the hold of an empty abstraction. It is essential to be clear. Dignity is an intrinsic quality in the precise sense that dignity is what it is in its being lived out, though equally in the refusal to let that be the case. The denial of dignity is always an attendant possibility. There is an inherent fragility within the intrinsic. Potentialities need not be actualized. ${ }^{25}$

While not argued for in these precise terms by Améry, what this formulation entails is that dignity is a potentiality awaiting actualization, though equally awaiting the refusal of its actualization. If refused, and this is Améry's position, it has to be affirmed by revolting against that which would refuse it. (Recognizing that refusal is a form of action.) In other words, dignity is not just given within an affirmative act, it is also what allows the affirmation to have become a form of sovereignty. In sum, revolt occurs "at the same time" (zugleich) as the seizing of fate. The later is itself a double movement comprised of a seizing for oneself that is also a seizing away. Doing, and an enacted undoing, one and the other, define action in this particular context. Revolt as affirmation is therefore creative because in seeking to undo the violence inherent in the constitution of being-withoutdignity it opens up the register of dignity as that which continues to find form. In this context, as noted above, dignity, thus the living out of dignity's 
affirmation, needs to be thought in terms of a potentiality coming to be actualized. Occurring as a result is, of course, the enacting of another mode of being. Though as always a type of caution is necessary. Openings that occur are tenuous. Guarantees are necessarily limited. Even within barbarism acting as resisting, resisting and revolt as delimiting modes of possible action, remain.

\section{4}

What has to be pursued is this set of doublings: i.e. doing and undoing, seizing for oneself and a seizing away. They provide a way of allowing for the body as a locus of affect, and yet at the same time allowing for the recognition of dignity that brings another body to the fore. The naturalization of the body would empty Améry's concerns of their insistent quality. The move from being-without-dignity to another body is not the return to an original body. Torture as unnatural needs another counter, a different counter measure. ${ }^{26}$ The body demands another possibility. In fact, it demands life as the affirmation beyond the continual threat of non-being, which can be also thought as the result of having been rendered inoperable. While inoperability is always produced, hence the link between inoperability and non-being, operability understood as action, as inherently workful, positions life as the counter to having been produced for death. While it cannot be pursued here it is possible to note that within the horrors on which Améry is dwelling there is both another thinking of death, as well as the life/death relation. Not only does death lose its essential and abstract quality - the distinction between having been produced for non-being and mere death will always obtain if only as a threat that continues - it is equally the case that what is maintained as essential is a potentiality for revolt that can always be translated as the potentiality to resist fate in the name of life.

Life, understood as a demand, can be taken up by pursuing some of the implications within one of the ways the body figures within Améry's text:

My body, debilitated and crusted with filth, was my calamity. My body, when it tensed to strike, was my physical-metaphysical dignity (meine physisch-metaphysische Würde). In situations like mine, physical violence is the sole means for restoring a disjointed personality. In the punch, I was myself (Ich war ich als ein Schlag) for myself and for my opponent. What I later read in Frantz Fanon's Les damnés de la terre, in a theoretical analysis of the behaviour of colonized peoples, I anticipated back then when I gave concrete social form to my dignity by punching a human face. To be a Jew meant the acceptance of the death sentence imposed by the world as a world verdict (Jude sein, das war Annahme der Todesurteil durch die Welt als eben eines Welturteil). To flee before it by 
withdrawing into one's self would have been nothing but a disgrace, whereas acceptance was simultaneously the physical revolt against it. I became a person not by subjectively appealing to my abstract humanity but by discovering myself within the given social reality (der gegebenen gesellschaftlichen Wirklichkeit) as a rebelling Jew and by realizing myself as one. 27

What is at work within the passage? As a beginning there is the body as the locus of affect. The affected body is the site on which the torturer would have worked. This is the body of a being-without-dignity. Hence, this is the site that has become degraded (and is being degraded by the continuity of indignity, by the reiteration of its enacted presence). Again, it is essential to note that indignity - the body as being-without-dignity - is produced as such. Améry is careful to write of degradation, or processes of degradation which are, of course, the continual recreation of indignity: the latter is Entwürdigungsprozeß. Thus, this is the undoing of dignity and the corresponding constitution of being-without-dignity. Precisely because it will have been constituted as such, this accounts for the force that continues to inhere in the word "dignity" (Würde).

Améry's body was "debilitated and crusted with filth." No matter how stark a description this is, starker because of its truth, that body provides another possibility. Within its "debilitated" state there was another quality. This showed itself when his body "was tensed to strike." Tensed, having the potential to act, being present on the verge of release, taken together they allowed the body, at that moment, to be a locus of his "physical-metaphysical dignity." The "strike," that act, unifies a self that has been taken apart. Within it, almost inhabiting the "strike," Améry becomes who he is. Operability as a mode of sovereignty begins to take over. Acting yields a self that came to exist both for himself, that is for Améry, and also for the other. This other is, of course, not an anonymous abstract other. The one he faces, the faced other, is his "opponent" (Gegner). The dissymmetry here was neither merely structural nor was it benign. The relation in this instance is comprised of a constituted disequilibrium of power forcing and reinforcing violence. Within that setting dignity emerges in the blow that was delivered. Its sense - understood as comprising, direction, meaning and presence as a feeling - depended on its occurring within a setting created by the constitution of a being-without-dignity. The question to be addressed is why does dignity emerge here? What is the link between dignity and the "punch" (Faustschlag)?

The answer begins to emerge in the next line of the passage under consideration. Hence, it is vital here to repeat the line in which it is staged. Améry wrote: 
To be a Jew (Jude sein) meant the acceptance of the death sentence imposed by the world as a world verdict (das war Annahme der Todesurteil durch die Welt als eben eines Welturteil). ${ }^{28}$

Death here is nothing other than a "judgment" (urteil) imposed by the world as the world's own judgement. In other words, it was the world that condemned Jews to death. The "world" constructs them as such. They become inoperable, stripped of sovereignty. The "opponent" therefore is both the guard, thus what amounts to the concrete other, whilst this other is also the one who in acting is imposing upon Améry's body the verdict of the world. It is always both. It is never just one. Hence, the other's body is not just one. Nor is the body just the body. The face of the guard and the face of the world are there at the same time. This is a counter presence; thus another form of at-the-same-timeness. What might be understood as its other face. In other words, what is struck, what the fist hits is that which is both the other's face, the clear enforcing face of brutality and yet that face is, at the same time, the face of the world. It is the latter because the "judgement of death" (der Todesurteil) is "a judgement of the world" (eines Welturteil.). Améry faced both. What then is the response? And it should be remembered that it is a response to processes that create indignity (Entwürdigungsprozeß) and thus it is not just a response to the face of the guard. Améry's body opposed more; and was itself always opposed by more. This "more" is however not an addition. It is an always already present "more" that structures the locus of judgment while creating the conditions for a response.

What is dismissed by Améry as a possible response to this predicament is that form of flight that separated the individual from the world and thus from the world's judgement. The latter had to be meet head on in a meeting that can be characterised as both worldly and world creating. Standing opposed to the world as the locus of "death sentence" is the world given within and as an affirmative act. The opposite is a type of "disgrace": this would be Schmach either as apatheia or the expressed preference not to act. Here the Jew as a being-without-dignity for whom the slip into non-being attends every moment is confronted by a radically divergent set of possibilities. Within them acting and not acting have a different set of entailments.

Stand taking as opposed to "flight," world creating as opposed to accepting the world's judgment, are modes of affirmation through which there would be a becoming human. A becoming in which what was attained was dignity, thus there would be an emergent operability. One would work with the other. This did not occur through a process in which the abstract human was evoked such that as a result an abstract form of particularity would then arise. Nor was it the affirmation of mere particularity. The contrary is the case. A specific stand was taken within a specific context. The latter, the context in question and the one in which the stand occurred, was 
described by Améry as "the given social reality" (der gegebenen gesellschaftlichen Wirklichkeit). What this means is that the identity that comes to be affirmed, and this affirmation is equally the affirmation of a form of dignity, takes place within that setting - the world - whose project was the creation of a subject without dignity, i.e. the continual recreation of a beingwithout-dignity. This occurs precisely because the act that affirmed identity could not have been enacted by an abstract human since the creation of a subject without dignity could not have pertained to an abstract human but only to identities that have been created. In the context of Améry's concerns this means the creation of the Jew as inseparable from the creation of what has already been described as being-without-dignity and therefore, as has already been noted, as "someone to be murdered" (ein zu Ermordender).

Abstraction, in this instance, could not be affirmed, against a process that produced the Jew as a being-without-dignity for the exact reason that these processes did not start with abstraction. On the contrary, and to stay close to Améry's own examples and thus argumentation, a start was made by the Nürnberger Gesetze which were passed in Reichstag in September 1935 which both undid identities, the identity between a Jew and German citizen, while simultaneously constructing identities. For any one constructed as a Jew from within this setting, and this act of construction was independent of any form of self-identification, while there was always a range of possible responses, for Améry the only possible response was one that gave action a particular quality. Action was not a mere occurrence. On the contrary action would be defined as the affirmation of a link between identity, dignity and world creation. This connection, and its doubled presence both play a fundamental role here. The connection comprises the movement that is already there in the countervailing sense of at-the-same-timeness. Here what that means is acting, in Améry's words, "as a rebelling Jew." One mode taken by this rebellion became the literal blow (Schlag) against the processes in which dignity was effaced or denied. 29

\section{5}

The opening beyond any reduction to the literal necessitates giving more attention to how the process of revolt can be understood as an actual counter measure, and thus how it brings with it a mode of philosophical thought whose concern is the world's transformation. (The latter - world transformation - has already been alluded to when reference was made to world creating, which is of course the countering of one world with another.) This is the possibility that inheres in the evocation, "Hear oh World"; the singular appeal to the world. The world thus appears within one of the senses of at-the-same-timeness that has already been noted. Jewish being as constituted in terms of being-without-dignity was defined by the imposition of a death sentence. It was imposed by the world. It was, to 
maintain Améry's formulation, a judgement made by the world. While it was the world that constructed the Jew as a being-without-dignity and therefore as "someone to be murdered," that world appeared, at the same time, in the face of the guard. To strike against the guard was to strike against that world. Hence the guard cannot be reduced to a single entity. There was an original relation between the guard and the world. One was an after-effect of the other. What this means is that the guard/world relation was itself also a founding relation that pertained within the setting of at-thesame-timeness. To strike the face of the guard was an act of rebellion precisely because it was not just the guard's face that was struck. It was this sense of at-the-same-timeness that provides the link to the other sense. It is this latter possibility that is locus of rebellion. What this sets in play is the possibility that the strike, the blow that lands on the face of the guard, is equally a strike against a world. The strike would then have opened a world, perhaps more exactly would have begun to open a world, the blow would have begun to be world creating. The blow therefore is an-arché in the precise sense that it provides an arché that has an indeterminate relation to any outcome. The blow is productive - potentiality - without having an already determined formal end. The world sustaining being-without-dignity would be displaced by the possibility of dignity's own self-affirmation. Dignity would have begun to recover its place in the world. All this occurs through action. What still needs to be incorporated into this account of world creating is the other modality of at-the-same-timeness.

The other modality was linked to the presence of fate. To affirm dignity meant to wrest fate from the identity (i.e. the identity determined in advance, fated identity) that had been constructed for the Jew, and thus wresting it from the process in which the Jew was constructed. It was this fated identity that became the site of struggle. What was taken on within that site is what can now be understood as the judgment imposed by the "world." The judgment constructed a subject; the subject in question, the one constructed, is "the degraded person (der entwürdigte), the subject as beingwithout-identity. This is the subject who acts. In acting as the one deemed to be without dignity, dignity comes to be affirmed. (Thus it should be remembered that to be without dignity means having been constituted as such.) That affirmation is the actualization of an inherent potentiality to-bedignified (a state of affairs that would amount to the affirmation of an original setting, an already present sense of operability as potentiality) which is both fragile and precarious. Affirming and attaining have an essential reciprocity. Inherent to dignity is its actualization. This is the site in which violence figures.

Violence as has been suggested individualizes insofar as it creates subjects, creates then by producing them as inoperable. Its object is a group, a race, a community or even an individual. They are constructed, created, such that they can be subject to literal violence. Hence death or torture 
follows. Améry's writings are positioned by that nexus. If there is a way through, then it can be located in the recognition that violence works through modes of construction. The pain of literal violence has to be understood in relation to the construction of the one on whom violence is perpetrated as the victim. There are different ways of understanding Améry's claim that torture "was not an accidental quality of this Third Reich, rather its essence" (sondern seiner Essenz). ${ }^{30}$ The way for it to be understood that is implicit in what has been suggested thus far is that it becomes the next move once a being-without-dignity has been created. This form of individuation allows for literal violence. That is why these specific processes of individuation can be described as violent. Indeed, it is possible to go further and suggest that literal violence is only possible if it is continuous with this mode of individuation. Rebellion is the refusal of having been constructed such that literal violence is simply continuous with the constructed state. The asserting of dignity becomes the attempt to undo this particular sense of continuity. Dignity is recovered to the extent that the discontinuity, the necessary discontinuity thus the one continually displacing any continuity, between modes of being and literal violence can be affirmed. That discontinuity, while precarious and thus enjoining a necessary vigilance, becomes the space whose maintenance allows human being in its diversity to appear. It becomes the space allowing for Jewish being.

1 Edmond J abès, El, ou le dernier livre (Paris: Editions Gallimard, 1973), 48.

2 I want to thank my friend and colleague Professor J ohn Lechte for our many discussions of questions of violence and how this harrowing topic is to be thought philosophically.

${ }^{3}$ All references to Amery are to the following: Jean Améry, At the Mind's Limits, trans Sidney Rosenfeld and Stella P. Rosenfeld (Bloomington: Indiana University Press, 1980) and J ean Améry, J enseits von Schuld und Sühne (Stuttgart: Klett-Cotta, 2014). In subsequent citations English pagination precedes the German. At times translations have been slightly modified. One of the most philosophically acute discussions of Améry can be found in the work of Magdalena Żótkoś. See, for example, her "Aporias of belonging: J ean Améry on "being a J ew without J udaism" and the tradition of conscious pariah," J ournal of European Studies, Vol. 44(4) (2014): 362-377.

${ }^{4}$ Emmanuel Levinas, Etre J uif (Paris: Éditions Payot \& Rivages, 2015).

${ }^{5}$ These terms are here are the formulations that are deployed by both Améry and Levinas. The link between Améry and this early text by Levinas warrants detailed attention in its own right. For an indication of how this might be done see: Joseph Rosen, "Suffering and Responsibility: Between Améry and Levinas," in On Jean Améry: Philosophy of Catastrophe, ed. Magdalena Żótkoś (Lanham: Lexington Books, 2011).

${ }^{6}$ While his approach is different, the attempt being made here to investigate the construction of identity, here the construction of what will continue to be identified as Jewish being, 
remembering that it is only one mode, has also been undertaken by J ean-François Lyotard. See his Heidegger et "les juifs" (Paris: Editions Galilée, 1988).

7 This position occurs in a number of different ways. For Fackenheim the Holocaust presents a "novum." There is as a result a demand on thought that entails that the concepts and categories that had pertained no longer exert any force automatically. For the detail of this position see his: Emil L. Fackenheim, To Mend the World: Foundations of Post-Holocaust J ewish Thought (Minneapolis: Indiana University Press, 1994). It should also be noted that Adorno confronts this topic in his lecture "Was bedeutet: Aufarbeitung der Vergangenheit?" in his Gesammelte Schriften, Bd. 10.2 (Frankfurt, Suhrkamp, 1977), 555-572. Engaging historical time and thus the present can no longer take refuge in the naturalization of historical time. There is an importantly different project. Stand taking involves holding a position within time. This occasions time's transformation. Again recourses to naturalism become both the betrayal of thought and the refusal of philosophical responsibility.

8 This failure could of course take many forms. What remains important is that the "worst" has to be maintained as an already present possibility. However the "worst" cannot be merely posited. It needs philosophical elaboration. For an important set of arguments uncovering the thinking of the "worst" in the writings of Derrida see Leonard Lawlor, "Animals Have No Hands": An Essay on Animality in Derrida," in CR: The New Centennial Review Vol. 7, No. 2, Fall (2007): 43-65. Specifically see pages 43-46.

9 I have examined the relationship between memorialization, form and the creation of images in my: "Now Still Absent: Eisenman's 'Memorial to the Murdered Jews of Europe,'" Architectural Theory Review Vol.8, No. 1 (2004) and "Forbidding, Knowing, Continuing. On Representing the Shoah," in J ean-Luc Nancy and Plural Thinking, ed. Marie-EveMorin and Peter Gratton (Albany: SUNY Press, 2014), 213-228.

${ }^{10}$ Améry's work is a powerful voice within a more general examination of the relationship between forgiveness, pardoning and the horrors perpetrated by National Socialism. Important contributions to this domain are also to be in found in: Jacques Derrida, Pardonner: L'impardonnable et l'imprescriptible (Paris: Galilée, 2012) which is in part a response to Vladamir Jankélévitch, L'imprescriptible (Paris: Editions du seuil, 1966). For a discussion of Jankélévitch that allows the connection to Améry to be established see: Jeffrey Bloechl, "Forgiveness and its Limits: An Essay on Vladamir J ankélévitch," in Vladamir Jankélévitch and the Question of Forgiveness, ed. Alan Udoff (Lanham: Lexington Books 2013), 97-110.

11 It is perhaps not surprising that both place and world are also evoked by Levinas in Etre J uif:

Etre juif, ce n'est pas seulement rechercher un refuge dans le monde, mais se sentir une place dans I'économie de l'etre," 50.

12 I have developed this position in great detail in my Working with Walter Benjamin. Recovering a Political Philosophy (Edinburgh: Edinburgh University Press, 2013).

13 This is why despite the value of Agamben's concept of "bare life," and despite how close it is to Améry's idea of that which is there to be murdered, there cannot be such an entity bare life other than which has been produced as such. Bareness is always produced and thus is never bare. The marks of production distinguish one sense of the particular from another. I have tried to argue for this position in the following: Andrew Benjamin, “The Inoperative Jew: Agamben's Paul," in Place, Commonality and Judgment. Continental Philosophy and the Ancient Greeks (London: Continuum, 2010), 136-158 and "Agamben on 'Jews' and 'Animals'" in Of Jews and Animals (Edinburgh: Edinburgh University Press, 2010), 113-130. See in addition the important 
paper by Ewa Ptonowska Ziarek, "Bare Life on Strike: Notes on the Biopolitics of Race and Gender," South Atlantic Quarterly Vol. 107, No 1 (2008): 89-105.

${ }^{14}$ Améry, At the Mind's Limits, 82/ 148.

15 One of the most remarkable literary examinations of this set up - namely, of having been identified and thus having to live an identity that has been created -concerns the character of Newman in Arthur Miller's Focus. The novel recounts how the construction of identity - J ewish being - is that with which the protagonist then has to live. Identity is positioned outside any form of affirmation. Hence it open up the space of what Améry calls rebellion. Though equally the same space is the opening for disaster. As has already been suggested the "worst" always endures as a possibility. See Arthur Miller, Focus (London: Secker \& Warburg, 1974).

16 There is of course no one summation of how this "question" is to be addressed. Its history has important complications. In part this has to do with the construction of the figure of the Jew within German thought. Two important studies in this domain are: Paul Lawrence Rose, German Question. Jewish Question. Revolutionary Antisemitism from Kant to Wagner (Princeton: Princeton University Press, 1990), and Jeffrey S. Librett, The Rhetoric of Cultural Dialogue: J ews and German from Moses Mendelssohn to Richard Wagner and Beyond (Stanford: Stanford University Press, 2000).

17 For a detailed history of these differing moments of constitution see: David Nirenberg, AntiJ udaism. The Western Tradition (New York: W. W. Norton, 2013).

${ }^{18}$ Améry, At the Mind's Limits, 86/ 150.

${ }^{19}$ Améry, At the Mind's Limits, 100/ 172.

${ }^{20}$ Arendt's claim is that "human dignity needs a new guarantee" and then the argument is that it:

can be found only in a new political principle, in a new law on earth, whose validity this time must comprehend the whole of humanity while its power must remain strictly limited, rooted in and controlled by newly defined territorial entities. Hannah Arendt, The Origins of Totalitarianism (New York: Schocken, 2004), ix.

Responding to the challenge she presents involves, as a start, investigating what a "new law on earth" would entail.

${ }^{21}$ Améry, At the Mind's Limits, 27-28/61.

22 Améry, At the Mind's Limits, 89/ 155.

${ }^{23}$ Hannah Arendt, The Origins of Totalitarianism (New York: Harcourt, Brace \& Co., 1951), 295. See in addition my "Redressing the Metaphysics of Nudity: Notes on Seneca, Arendt and Dignity." (Forthcoming)

${ }^{24}$ Améry, At the Mind's Limits, 82/ 155.

25 The question of the "intrinsic" is complex. This is not a claim about natural rights. Indeed, any recourse to naturalism is to be resisted. The argument can draw on an important distinction drawn by Peg Birmingham between natural rights and what she describes as "a human right that emerges from the event of natality itself." Peg Birmingham, Hannah Arendt and Human Rights: The Predicament of Common Responsibility (Indiana: Indiana University Press, 2006), 92.

26 I have developed the concept of the counter measure in a number of places. See, for example, the discussion in my Working with Walter Benjamin. 
${ }^{27}$ Améry, At the Mind's Limits, 91/ 158.

${ }^{28}$ Améry, At the Mind's Limits, 91/ 158.

29 The "blow" (Schlag) plays an important role in the writings of Walter Benjamin. For a detailed study of this motif in Benjamin's writings see: David Ferris, "Politics of the Useless: The Art of Work in Heidegger and Benjamin," in "Sparks will Fly": Benjamin and Heidegger, ed. Dimitris Vardoulakis and Andrew Benjamin (New York: SUNY Press, 2013), 259-282.

${ }^{30}$ Améry, At the Mind's Limits, 23/55. 